\title{
44. ORIGIN OF ORGANIC-CARBON-RICH MID-CRETACEOUS LIMESTONES, MID-PACIFIC MOUNTAINS AND SOUTHERN HESS RISE ${ }^{1}$
}

\author{
Walter E. Dean and George E. Claypool, U.S. Geological Survey, Denver, Colorado \\ and \\ Jörn Thiede, University of Oslo, Oslo, Norway
}

\begin{abstract}
Limestones of mid-Cretaceous age containing as much as 8.6 percent organic carbon were cored at one site (463) in the Mid-Pacific Mountains and at two sites $(465,466)$ on southern Hess Rise, central North Pacific Ocean, during Leg 62 of the Deep Sea Drilling Project. In the Mid-Pacific Mountains, three layers containing more than 2\% organic carbon are associated with volcanic ash in silicified limestone of early Aptian age ( -112-113 m.y. old), a time when the site was south of the equator and considerably shallower than at present $(2525 \mathrm{~m})$. The beds of laminated, organiccarbon-rich limestone, implying deposition in an oxygen-deficient environment, are interbedded with normal pelagic limestones. This sequence lies on interbedded pelagic limestones and clastic limestones containing locally derived shallow-water carbonate debris, and it is overlain by interbedded green, gray, and pink limestones. The organic-carbonrich strata on southern Hess Rise are dark-olive, laminated limestones with rare interbeds of altered volcanic ash of the late Aptian to early Cenomanian ( $\sim 98$ to $103 \mathrm{~m}$.y. old), a time when the site was passing under the equatorial highproductivity zone and subsiding from shallow to intermediate water depths. The organic-carbon-rich limestone sequence overlies volcanic basement (trachyte) in this part of Hess Rise. The association of volcanogenic sediments with organic-carbon-rich strata on Hess Rise is not as striking as in the Mid-Pacific Mountains, but the occurrences do suggest a coincidence of mid-plate volcanic activity and accumulation of organic matter at intermediate water depths in the tropical North Pacific Ocean during the mid-Cretaceous.

Pyrolysis assays indicate that most of the organic matter in the limestone on Hess Rise is composed of lipid-rich kerogen derived from marine organisms. Limestones from the Mid-Pacific Mountains contain lower concentrations of organic matter. Pyrolysis assays and extractable hydrocarbons indicate that the organic matter in samples from Hole 463 is also predominantly of marine origin, and that contributions of terrigenous organic matter were probably minor. Analyses of stable carbon isotopes indicate that the organic carbon in all analyzed samples is isotopically light $\left(\delta^{13} \mathrm{C}\right.$ -24 to $-29 \%$ ) relative to most modern marine organic carbon $\left(\delta^{13} \mathrm{C}-9\right.$ to $\left.-30 \%\right)$, and that the lightest carbon $\left(\delta^{13} \mathrm{C}\right.$ -28 to $-29 \%$ ) is also the most lipid-rich.

The organic-carbon-rich mid-Cretaceous limestones on Hess Rise, the Mid-Pacific Mountains, and other elevated plateaus and seamounts in the Pacific Ocean are approximately equivalent in age (mid-Cretaceous, $\sim 85-120$ m.y.) to organic-carbon-rich lithofacies elsewhere in the world ocean, particularly in the Atlantic Ocean and parts of the Indian Ocean. However, strata of equivalent age deposited in the Pacific Ocean at greater depths do not contain any carbonrich horizons. This observation, together with the evidence that the plateau sites were considerably shallower and close to the equator during the mid-Cretaceous, suggests that an expanded mid-water oxygen minimum, together with local restrictions in circulation, may have resulted in the preservation of organic matter in an oxygen-deficient environment where the oxygen minimum impinged on elevated platforms such as Hess Rise and the Mid-Pacific Mountains.
\end{abstract}

\section{INTRODUCTION}

The lower Aptian section (Lithologic Unit III; Cores $67-71 ; 587.7-632.5 \mathrm{~m}$ sub-bottom) at DSDP Site 463 in the northwestern Mid-Pacific Mountains consists of white, gray, and green limestone and silicified limestone, interbedded with thin $(1-30 \mathrm{~cm})$ beds of tuffaceous limestone and (in Core 70) beds of laminated, greenish-black carbonaceous limestone that contains as much as $7.5 \%$ organic carbon. (Degree of silicification is highly variable, particularly in Hole 463 . Consequently, many lithologies described as "limestone" more correctly should be called marlstone, or even calcareous mudstone; we use the term limestone with the realization that much of the original carbonate has been replaced by silica.) The oldest sedimentary lithologic unit at Site $\mathbf{4 6 5}$

\footnotetext{
${ }^{1}$ Initial Reports of the Deep Sea Drilling Project, Volume 62.
}

on southern Hess Rise (Unit II, Hole 465A; Cores 26-40; 276-411.7 m sub-bottom; upper Albian to lower Cenoanian) overlies volcanic basement (trachyte) and consists of laminated, olive-gray limestone that contains as much as $8.6 \%$ organic carbon. The lateral equivalent of this unit $35 \mathrm{~km}$ to the northeast at Site 466 consists of olive-gray nannofossil chalk and limestone of late Albian age (Lithologic Unit II; Cores $28-35$; 245.5-312 m subbottom) that contains as much as $8.1 \%$ organic carbon.

Strata of the about the same age (Barremian to Turonian) containing horizons rich in organic carbon have been cored on other oceanic plateaus in the Pacific (Manihiki Plateau, Horizon Guyot, Shatsky Rise, northern Hess Rise), and at a number of sites in the Atlantic and Indian oceans (Schlanger and Jenkyns, 1976; Fischer and Arthur, 1977; Ryan and Cita, 1977; Thiede and van Andel, 1977; Gardner et al., 1978; Arthur, 1979; Arthur and Schlanger, 1979; Tucholke and Vogt, 1979). 
The abundance of organic-carbon-rich strata of midCretaceous age has led some investigators to conclude that the preservation of organic matter is the result of a worldwide oceanic anoxic event that produced an expanded oxygen minimum in middle to deep waters in the Pacific Ocean, and complete or almost complete deoxygenation of bottom waters in the Atlantic Ocean and parts of the Indian Ocean (e.g., Schlanger and Jenkyns, 1976; Fischer and Arthur, 1977; Ryan and Cita, 1977; Thiede and van Andel, 1977; Arthur and Schlanger, 1979).

A worldwide anoxic event implies that there was insufficient oxygen in waters over a large part of the world ocean to oxidize organic material accumulating on the sea floor, because of one or more of the following factors: (1) increased biological oxygen demand in the water column and sediments resulting from increased surface-water productivity and (or) influx of terrigenous organic matter, (2) a reduced rate of bottom-water circulation, (3) an increased rate of sedimentation, and (4) reduced solubility of oxygen in warmer waters.

The purpose of this paper is to describe the physical and chemcial characteristics of the organic-carbon-rich strata from DSDP Sites 463,465 , and 466 , and to examine these characteristics for evidence of origin of the organic matter and origin of the anoxic conditions that resulted in the preservation of the organic matter.

\section{DESCRIPTIONS OF ORGANIC-CARBON-RICH ROCKS}

\section{Site 463}

The organic-carbon-rich rocks at Site 463 (Fig. 1) occur together with volcanic ash (Fig. 2) in an unusual

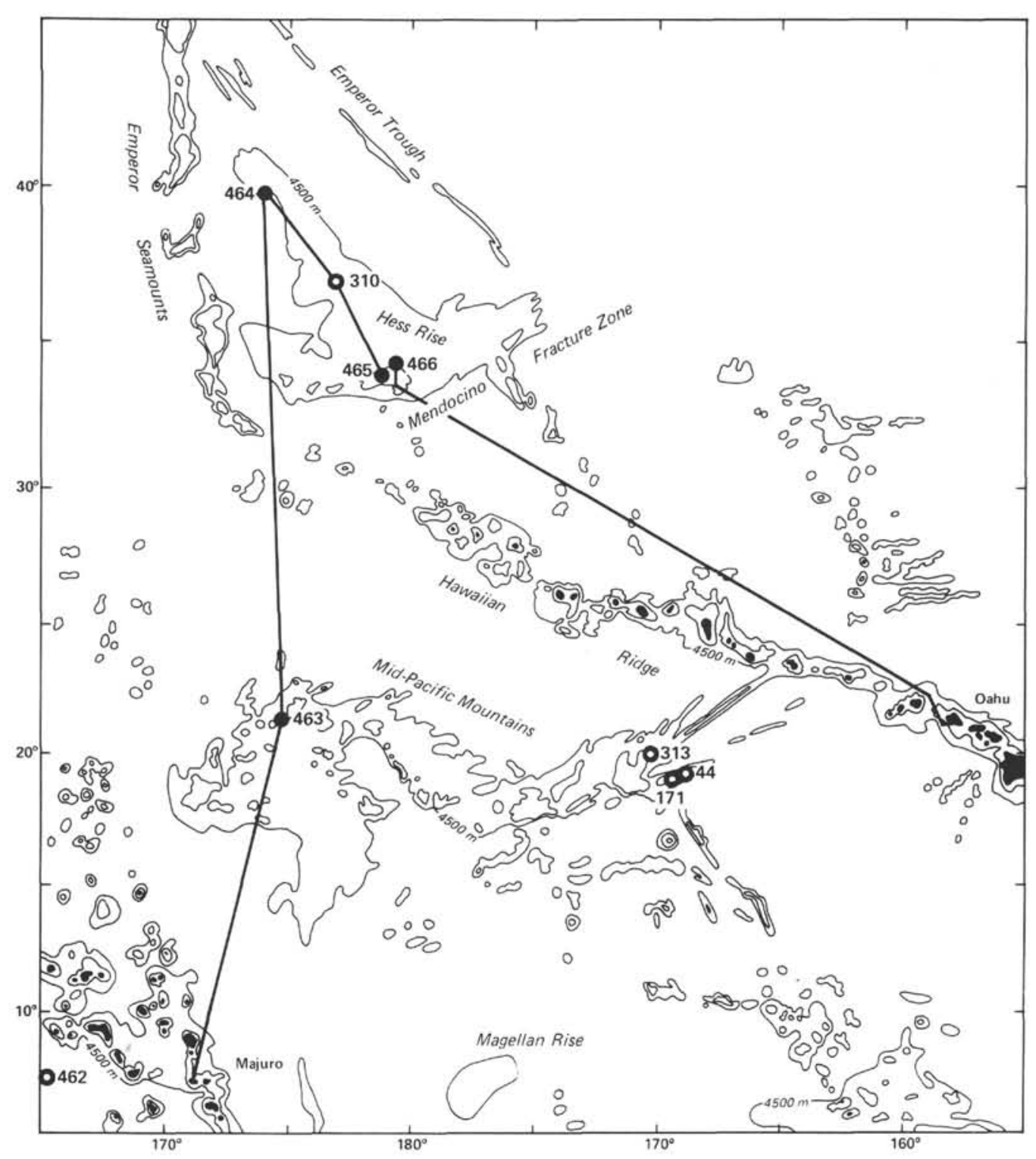

Figure 1. Map showing general bathymetry of the central North Pacific Ocean and locations of DSDP Site 463 in the Mid-Pacific Mountains and Sites 465 and 466 on Hess Rise. 


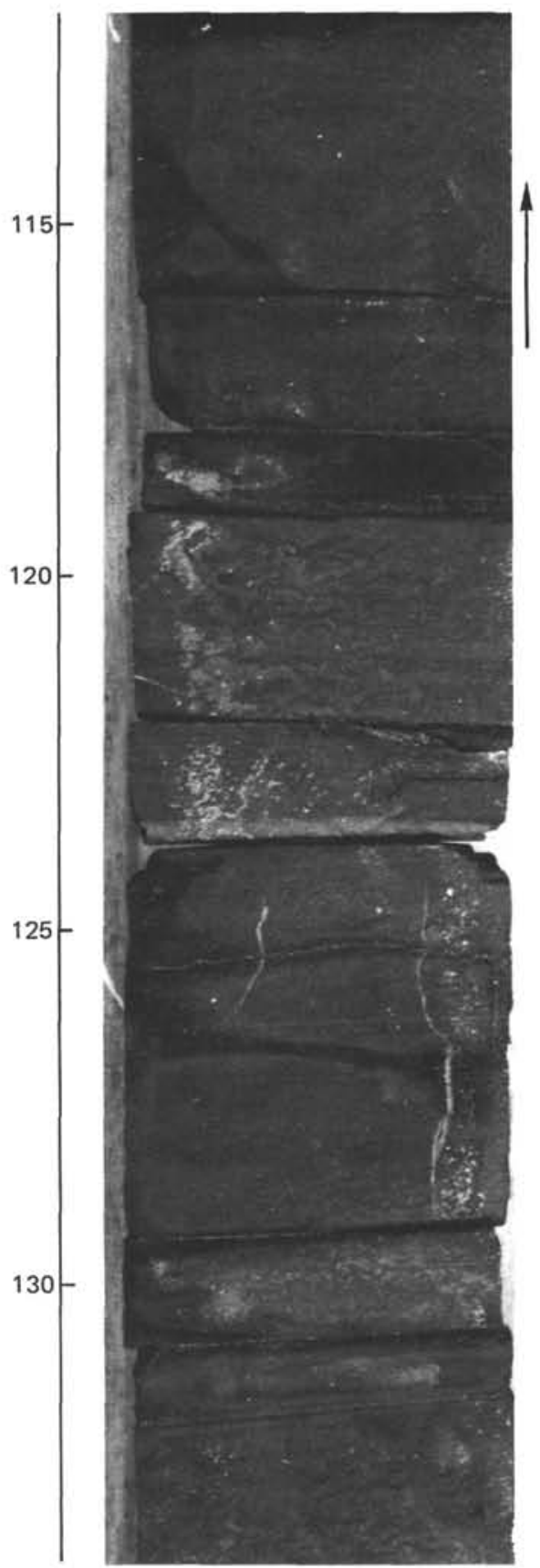

Figure 2. Tuff- and organic-carbon-rich siliceous limestone, Hole 463 , Core 70 , Section 5, 112 to $134 \mathrm{~cm}$. Scale in millimeters.

carbonate-poor interval within the Lower Cretaceous carbonate section that caps the western Mid-Pacific Mountains. This interval contains several layers of dark, laminated, silicified limestone containing up to $7.6 \%$ organic carbon (Fig. 3) intercalated within gray, fine-grained, highly silicified limestone of early Aptian age (Chiastozygus litterarius nannofossil zone; Cepek, this volume). A detailed lithologic log, age scale, and concentrations of $\mathrm{CaCO}_{3}$ and organic carbon in Cores 69 to 72 are combined in Figure 4.
The age scale in Figure 4 is based on linear interpolation between the upper and lower boundaries of the Chiastozygus litterarius nannofossil zone (112-115 m.y.; van Hinte, 1976). If we assume that the sedimentation rate was constant during this interval, then the ages of individual intervals with high concentrations of organic carbon can be estimated within about 10,000 years (Fig. 4).

The organic-carbon concentrations in samples from Core 70 exceed $2 \%$ in three intervals representing about 140,000 years. The earliest and shortest interval began about 113.2 m.y. ago, the second interval began about 113.18 to 113.19 m.y. ago, and the third interval began about 113.08 to 113.09 m.y. ago. The laminated intervals within dark-gray, mottled, silicified limestone suggested that there may have been cyclic development of a depositional environment favorable for the preservation of organic carbon, but many of the laminated intervals do not contain particularly high concentrations of organic carbon. The three organic-carbon-rich intervals have very sharp lower boundaries, indicating that oxygen-poor conditions were established rapidly. The upper boundaries are gradational, which suggests that it took a few thousand to a few tens of thousands of years for the environment to return to its original oxygenated condition. In general, variations in $\mathrm{CaCO}_{3}$ parallel those in organic carbon (Fig. 4).

The rocks in Cores 70 and 71 in Hole 463 (Fig. 4) are dominantly highly silicified limestones with some chert and a few layers of volcanic ash. Radiolarians are abundant, but poorly preserved (recrystallized; Fig. 5) compared with the much better-preserved radiolarians above and below, which suggests a biogenic source of silica for diagenetic silicification of the limestones, and hence a high surface-water fertility, although the site was situated far south of the equatorial divergence during Early Cretaceous time (Sayre, this volume).

Much of the original carbonate also has been replaced with silica, and as a result the content of $\mathrm{CaCO}_{3}$ is generally less than $30 \%$ and the concentrations of $\mathrm{Si}$ are as high as $40 \%$ (Dean, this volume).

The most remarkable sedimentary structures in Cores 69 through 72 are the laminations in the dark-gray, clayey intervals intercalated with the bluish-white to dark-greenish-gray, mottled limestones. The laminated intervals range from a few centimeters to more than 60 $\mathrm{cm}$ thick, but only three of these intervals contain concentrations of organic carbon greater than $2 \%$. The darker intervals occur throughout Cores 69 through 72, but they are most abundant in Cores 70 and 71 where it is difficult to distinguish them from thin volcanic-ash layers.

\section{Sites $\mathbf{4 6 5}$ and 466}

The organic-carbon-rich laminated limestone (Fig. 6) at Site 465 on southern Hess Rise is 136 meters thick and represents about 5 m.y. from the late Albian to the early Cenomanian (Fig. 7). The lateral equivalent of this unit at Site 466 consists of faintly laminated nannofossil chalk and limestone that is generally similar in lithology 


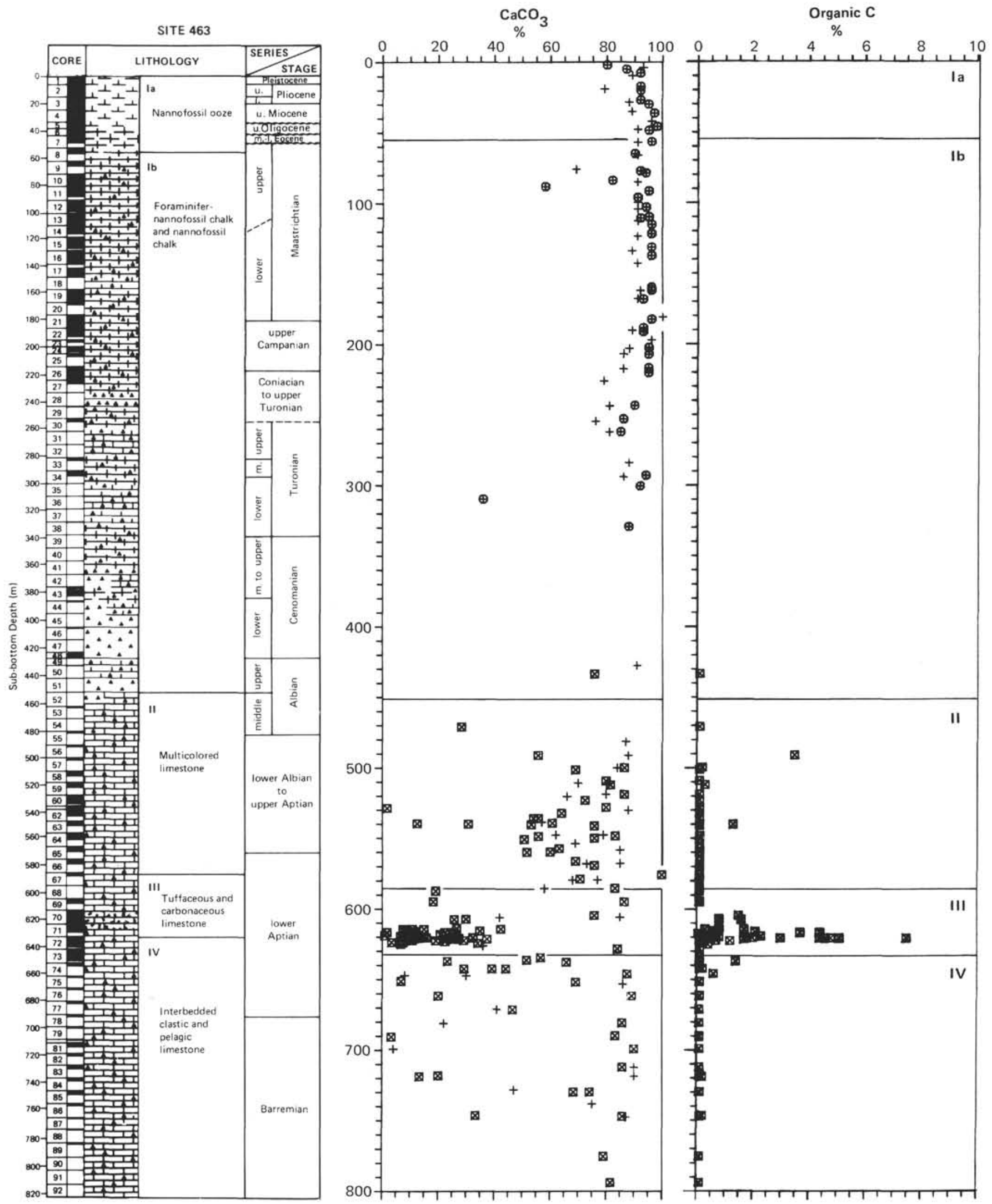

Figure 3. Lithology, age, and concentration of $\mathrm{CaCO}_{3}$ and organic carbon in samples from Cores 69 and 72 , Hole 463 . The interval is entirely within the Chiastozygus litterarius nannofossil zone (Cores 65-78; Cepek, this volume). The interpolated ages are based on the time scale of van Hinte (1976). 


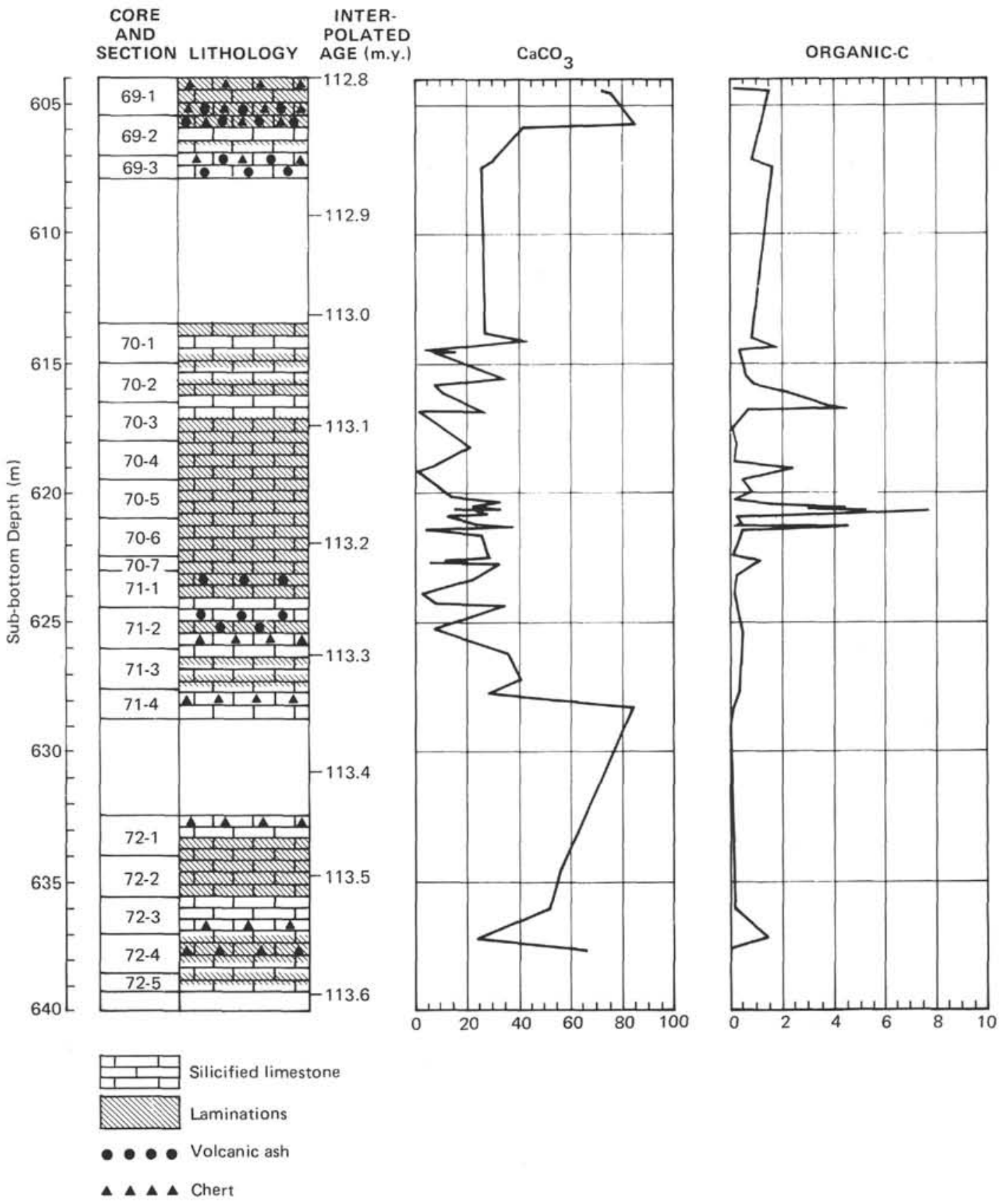

Figure 4. Lithologic summary and concentrations of $\mathrm{CaCO}_{3}$ and organic carbon, Hole 463. Organic-carbon concentrations were determined with a Leco carbon analyzer; $\mathrm{CaCO}_{3}$ concentrations were determined either by Leco at DSDP (squares), by Leco at the University of Oslo (circles), or shipboard carbonate-bomb (plus signs). All values are in per cent dry weight.

to the laminated limestone at Site 465 but slightly lighter in color. However, the chalk and limestone at Site 466 represent only about $1 \mathrm{~m} . \mathrm{y}$. during the late Albian in about 66.5 meters of section.

The lamination of the limestone at Site 465 is the result of concentrations of radiolarians and foraminifers and flaser-like laminae containing streaks of dark organic(?) material in a matrix of micritic calcite (Fig. 8 ). Chert is common throughout the laminated limestone, but silicification of the limestone is slight and confined mainly to rare, thin interbeds of gray, massive to faintly laminated limestone. Radiolarians are common, but most have been replaced by calcite. Varying degrees of silicification have resulted in considerable variation in concentrations of carbonate in the laminated limestone, although most samples contain more than $60 \% \mathrm{CaCO}_{3}$ (Fig. 7). The laminated limestone contains common redeposited organic materials, including mollusk fragments, shelf benthic foraminifers, and radiolarians (see biostratigraphic summary in Site 465 


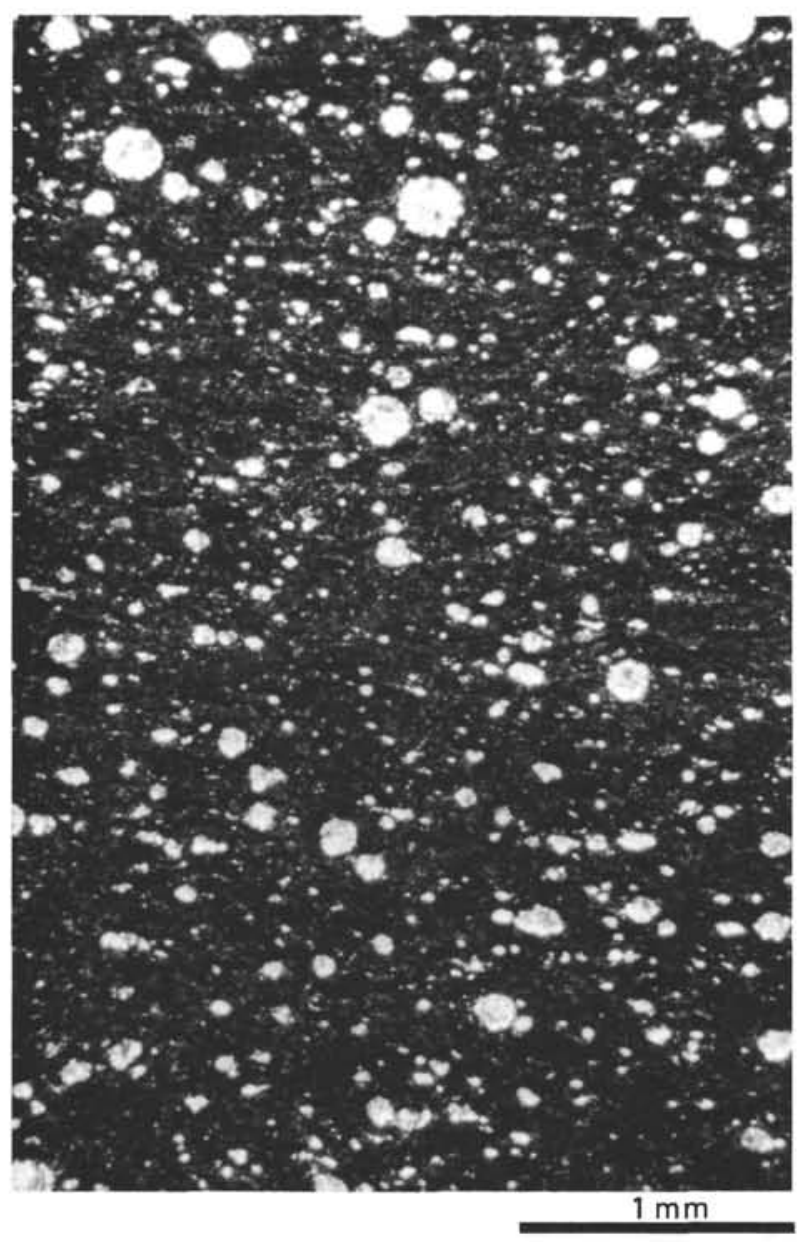

Figure 5. Recrystallized radiolarians in organic-carbon-rich siliceous limestone, Hole 463, Core 70, Section 5, $135 \mathrm{~cm}$. Cross-polarized light. $\mathrm{Bar}=1 \mathrm{~mm}$.

report, this volume). Concentrations of organic carbon in samples of the laminated limestone from Hole $465 \mathrm{~A}$ are as high as $8.6 \%$, but most are less than $5.0 \%$ (Fig. 7); there are no apparent differences between laminated limestones containing higher concentrations of organic carbon and those containing lower concentrations.

\section{METHODS}

The amount and type of organic matter in samples of midCretaceous limestones from Holes $463,465 \mathrm{~A}$, and 466 was evaluated by routine petroleum-source-rock techniques and by determinations of stable-carbon-isotope ratios.

Carbonate carbon was determined gravimetrically by acidification of a powdered sample to dissolve carbonate. Organic carbon was determined gravimetrically on the acid-insoluble residue and solution by chemical oxidation (with hot chromic acid) to convert organic matter (including acid-soluble forms) to carbon dioxide. Pyrolysis assay was by Rock-Eval (Espitalié, et al, 1977), except for samples containing less than $0.5 \%$ organic carbon, which were analyzed on a pyrolysis apparatus that permits use of a larger sample. (Use of trade names in this report is for descriptive purposes only and does not constitute endorsement by the U.S. Geological Survey.)

Stable-carbon-isotope ratios were determined by standard techniques. Oven-dried $\left(40^{\circ} \mathrm{C}\right)$ powdered sample was reacted with $2 \mathrm{~N} \mathrm{HCl}$ to dissolve carbonate. The residue was centrifuged, decanted, washed three times, dried, and combusted under oxygen pressure in an apparatus similar to that described by Kaplan et al. (1970). The resulting

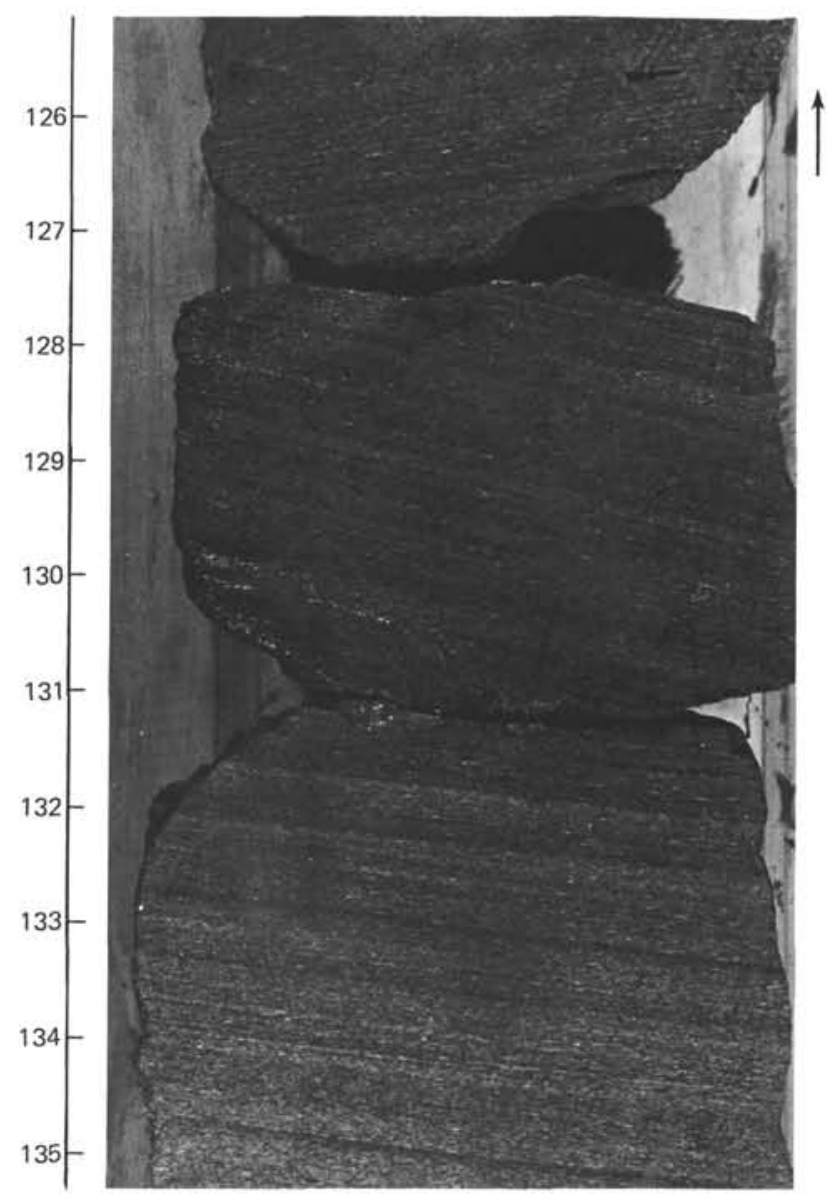

Figure 6. Laminated organic-carbon-rich limestone, Hole 465A, Core 29 , Section 1,125 to $135 \mathrm{~cm}$. Scale in millimeters.

$\mathrm{CO}_{2}$ was purified, and isotope ratios were determined with a 6 -inch Neir-type double-collecting mass spectrometer equipped with a double inlet system. Results are reported in the usual $\delta$-notation relative to the PDB marine-carbonate standard.

\section{RESULTS}

Results of pyrolysis assays of 34 samples are given in Table 1 in terms of their yields of pyrolytic hydrocarbon (HC) and carbon dioxide, normalized by organiccarbon content (i.e., hydrogen index, $\mathrm{mg} \mathrm{HC} / \mathrm{g} \mathrm{C}$; and oxygen index, $\mathrm{mg} \mathrm{CO} / \mathrm{g} \mathrm{C}$, respectively). These indexes are proportional to the elemental $\mathrm{H} / \mathrm{C}$ and $\mathrm{O} / \mathrm{C}$ ratios of organic matter, and can be used in the Van Krevelentype diagram to evaluate types of organic matter (Fig. 9; Tissot and Welte, 1978, p. 445).

The dashed lines in Figure 9 indicate pathways of thermochemical transformation for three different endmember types of sedimentary organic matter. Algal-rich and (or) microbically reworked organic matter gives rise to Type I kerogen, which has a high initial $\mathrm{H} / \mathrm{C}$ ratio. This type of organic matter is relatively rare and is most characteristic of certain lacustrine environments. Type II kerogen originates from marine sapropelic organic matter and is the general type of kerogen in most typical petroleum source rocks (Tissot et al., 1974). Type III kerogen is lower in hydrogen and higher in oxygen and 

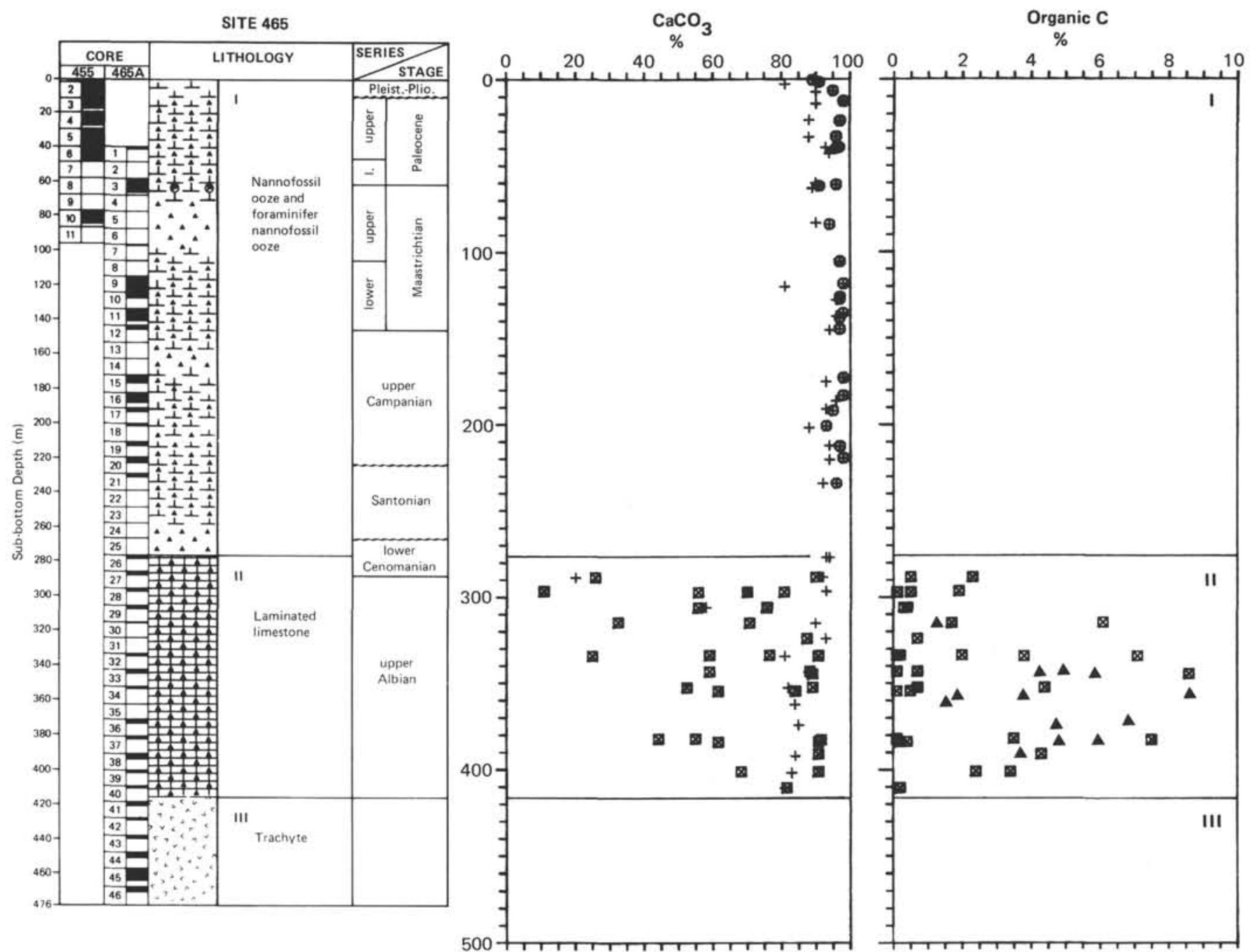

Figure 7. Lithologic summary and concentrations of $\mathrm{CaCO}_{3}$, and organic carbon, Site 465. Organic-carbon concentrations were determined with a Leco carbon analyzer (squares), or by wet combustion (triangles; data from Table 1); $\mathrm{CaCO}_{3}$ concentrations were determined either by Leco at DSDP (squares), by Leco at the University of Oslo (circles), or by shipboard carbonate-bomb (plus signs). All values are in per cent dry weight.

includes the type of organic matter originating from terrestrial plants and highly weathered, chemically inert organic matter of unknown origin.

The results plotted in Figure 9 indicate that most of the samples from Holes $465 \mathrm{~A}$ and 466 contain Type II organic matter; a few samples are intermediate between Type II and Type III. Most of the samples from Hole 463 contain organic matter which gives hydrogen indexes of less than $150 \mathrm{mg} \mathrm{HC} / \mathrm{g} \mathrm{C}$, and thus resembles Type III kerogen. The oxygen indexes for most of the samples from Hole 463 were anomalously high, or were not measured because of the use of a different pyrolysis apparatus, and are plotted at the level of their hydrogen index just off scale to the right of Figure 9. All the samples with hydrogen indexes less than $150 \mathrm{mg} \mathrm{HC} / \mathrm{g}$ $\mathrm{C}$ had extremely low contents of total organic carbon $(0.5 \%$ or less). Samples from Hole 463 with greater than $0.5 \%$ organic carbon have hydrogen indexes that range from 196 to $478 \mathrm{mg} \mathrm{HC} / \mathrm{g} \mathrm{C}$ and are intermediate between Type II and Type III organic matter (Fig. 9). This suggests that limestones at Site 463 in the Mid-Pacific
Mountains may contain variable mixtures of typical marine (Type II) organic matter and terrestrial or highly oxidized marine organic matter (Type III), the proportion of marine organic matter increasing with increasing total organic-matter content.

In order to test for the presence of terrestrial organic matter in samples from Hole 463 , the extractable bitumen of selected samples was analyzed for terrestrialplant marker compounds. Higher-molecular-weight, oddcarbon-numbered $n$-alkanes $\left(n-\mathrm{C}_{27}, n-\mathrm{C}_{29}, n-\mathrm{C}_{31}\right.$, and $n-\mathrm{C}_{33}$ ) are derived from cuticular waxes of higher plants, and their abundance in immature sediments indicates the relative contribution of terrestrial organic matter (Tissot and Welte, 1978; Claypool and Baysinger, in press). Results of solvent extraction and column chromatography are summarized in Table 2. Gas chromatograms of the saturated-hydrocarbon fractions (heptane eluates) are shown in Figure 10.

Samples from Cores 59 and 72, Hole 463 (Figs. 10A and $10 \mathrm{C})$ are almost devoid of organic matter $(0.03$ and $0.01 \%$ organic carbon, respectively). However, a high 

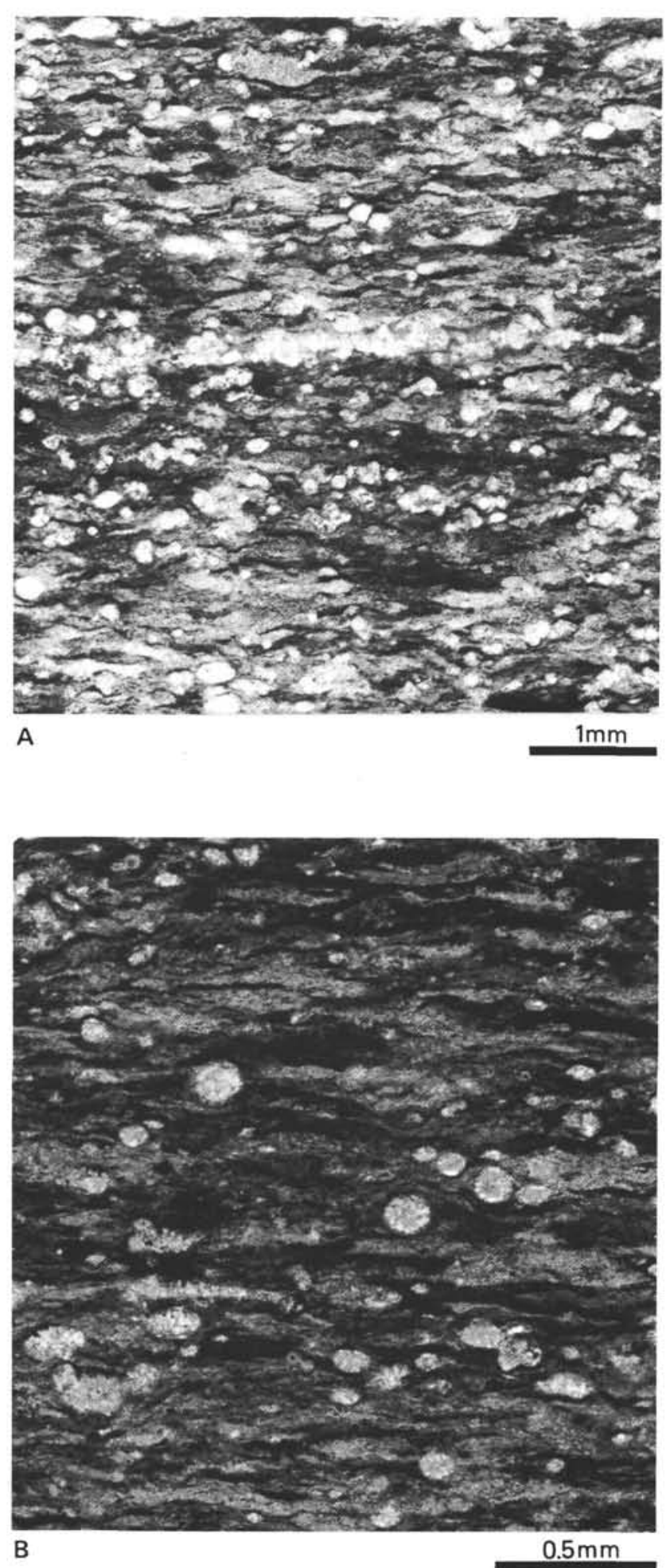

Figure 8. Laminated organic-carbon-rich limestone, Hole $465 \mathrm{~A}$, showing concentrations of radiolarians (A) and streaks of dark organic(?) material in a matrix of micritic calcite (A and B).

A. Core 37, Section 1, $134 \mathrm{~cm}$; cross-polarized light; bar $=2 \mathrm{~mm}$.

B. Core 28 , Section 2, $53 \mathrm{~cm}$; cross-polarized light; bar $=0.5 \mathrm{~mm}$. proportion of the organic matter in these samples is present as extractable hydrocarbons which show little or no sign of odd-carbon-numbered $n$-alkanes in the range $n-C_{25}$ to $n-C_{33}$. The other sample from Hole 463 (Fig. 10B) has a higher content of organic matter (estimated $2.5 \%$ organic carbon) and does show distinct oddcarbon-numbered $n$-alkane predominance, especially in the range $n-\mathrm{C}_{33}$ to $n-\mathrm{C}_{35}$.

The region of the chromatogram where $n$-alkanes $n-\mathrm{C}_{27}$ to $n-\mathrm{C}_{31}$ are present is obscured by the large unresolved hump representing the sterane-triterpane biological marker compounds characteristic of autochthonous marine organic matter. This indicates that contributions of terrestrial organic matter at Site 463 were probably minor. In those samples where a significant amount of organic matter is preserved, it is dominantly of marine origin.

This is illustrated by the analysis of a sample of typical laminated limestone from Hole 465A (Fig. 10D). This sample is richer in organic matter $(3.6 \%$ organic carbon), but only a small fraction of the extractable organic matter is present as hydrocarbons. The saturated-hydrocarbon distribution shown in Figure 10D is similar to that of Sample 463-70-6 (Fig. 10B), and this indicates a similar dominantly marine source of organic matter, with a minor contribution from terrestrial plants.

Results of analyses of stable-carbon-isotope ratios, expressed as $\delta^{13} \mathrm{C}$ relative to the PDB marine-carbonate standard, are listed in Table 1 and plotted in Figure 11 versus the hydrogen index (also listed in Table 1).

All the $\delta^{13} \mathrm{C}$ values in Table 1 and Figure 11 are isotopically light (i.e., enriched in ${ }^{12} \mathrm{C}$ ) relative to most modern marine organic matter, are within the ranges for terrestrial organic matter and petroleum, and are similar to $\delta^{13} \mathrm{C}$ values from other organic-carbon-rich midCretaceous (Aptian to Cenomanian) rocks from other localities (Fig. 12).

The samples that contain the most-lipid-rich, presumably autochthonous marine organic matter (hydrogen indexes greater than $400 \mathrm{mg} \mathrm{HC} / \mathrm{g} \mathrm{C}$ ) also have the most-negative $\delta^{13} \mathrm{C}$ values $(-27.4$ to $-28.8 \%$ ). Thus, organic matter which appears to be most marine-like in chemical composition appears to be most terrestrial-like in carbon-isotope composition.

\section{MARINE VS. TERRESTRIAL SOURCES OF ORGANIC MATTER}

Sites 463 (present water depth $2525 \mathrm{~m}$ ), 465 (present water depth $2161 \mathrm{~m}$ ), and 466 (present water depth 2665 m) were as much as $\mathbf{2 0 0 0}$ meters shallower and farther south and east during the mid-Cretaceous when the organic-carbon-rich strata were deposited (see site reports, this volume).

Using the rotation model of Lancelot and Larson (1975) and Lancelot (1978) for the Pacific plate, Site 463 would have been approximately at $21^{\circ} \mathrm{S} 112$ to $113 \mathrm{~m}$.y. ago, during deposition of organic-carbon-rich strata at that site (see Sayre, this volume). Site 465 would have 
Table 1. Summary of carbon, $\delta^{13} \mathrm{C}$, and pyrolysis analyses of samples of organic-carbon-rich limestones from DSDP Sites 463,465 , and 466.

\begin{tabular}{|c|c|c|c|c|c|c|c|}
\hline $\begin{array}{c}\text { Sample } \\
\text { (interval in } \mathrm{cm} \text { ) }\end{array}$ & Lithology & $\begin{array}{c}\text { Organic } \\
\text { Carbon } \\
(\%)\end{array}$ & $\begin{array}{c}\text { Carbonate } \\
\text { Carbon } \\
(\%)\end{array}$ & $\begin{array}{c}\delta^{13} \mathrm{C} \text { org. } \\
(\% \circ)\end{array}$ & $\begin{array}{c}\text { Hydrogen } \\
\text { Index } \\
\text { (mg HC/g C) }\end{array}$ & $\begin{array}{c}\text { Oxygen } \\
\text { Index } \\
\left(\mathrm{mg} \mathrm{CO}_{2} / \mathrm{g} \mathrm{C}\right)\end{array}$ & $\begin{array}{l}\text { Temperature } \\
\text { of Maximum } \\
\text { Yield }^{\mathrm{c}} \\
\left({ }^{\circ} \mathrm{C}\right)\end{array}$ \\
\hline $463-56-1,15-19$ & Greenish-gray limestone & 0.06 & 7.5 & - & 85 & - & - \\
\hline $59-3,73-83$ & Greenish-gray limestone & 0.03 & $-f$ & -25.7 & 29 & - & - \\
\hline $69-1,38-44$ & Bluish-white limestone & 0.07 & 8.7 & - & 55 & 929 & - \\
\hline $70-6,29-35$ & Greenish-black limestone & 0.59 & - & -27.0 & 200 & 119 & 437 \\
\hline $70-6,39-42$ & Greenish-black limestone & 4.4 & - & -27.7 & 478 & 40 & 429 \\
\hline $71-1,90-95$ & Tuffaceous limestone & 0.10 & 0.3 & - & 68 & 389 & - \\
\hline $72-4,25-30$ & Dark green-gray limestone & 0.26 & 3.4 & - & 33 & 521 & - \\
\hline $72-4,132-140$ & Dark green-gray limestone & 0.01 & - & -25.4 & 147 & - & - \\
\hline $463 \mathrm{~d}$ & Tuffaceous limestone & 1.6 & 0.6 & -24.1 & 196 & 83 & 409 \\
\hline $463^{\mathrm{d}}$ & Tuffaceous limestone & 0.71 & 7.8 & - & 296 & 101 & 397 \\
\hline $463^{\mathrm{d}}$ & Tuffaceous limestone & 0.51 & 5.6 & - & 25 & 107 & - \\
\hline $463^{d}$ & Tuffaceous limestone & 0.09 & 8.0 & - & 120 & 1422 & - \\
\hline 465A-30-1, 76-79 & Olive laminated limestone & 1.2 & 9.2 & -27.3 & 267 & 30 & 404 \\
\hline $33-1,22-24$ & Olive laminated limestone & 0.88 & 9.7 & -28.7 & 530 & 48 & 402 \\
\hline $33-1,41-48$ & Olive laminated limestone & 5.0 & - & -27.4 & 573 & 52 & 423 \\
\hline $33-2,21-23$ & Olive laminated limestone & 4.2 & 10.2 & -28.0 & 649 & 94 & 389 \\
\hline $33-2,85-90$ & Olive laminated limestone & 5.8 & - & -27.4 & 590 & 41 & 404 \\
\hline $34-1,65-69$ & Olive laminated limestone & 8.6 & - & -27.4 & 673 & 34 & 409 \\
\hline $34-1,91-97$ & Olive laminated limestone & 3.9 & 9.5 & -28.2 & 589 & 53 & 406 \\
\hline $35-1,0-6$ & Olive laminated limestone & 1.8 & 8.8 & -27.9 & 590 & 60 & 405 \\
\hline $35-1,8-10$ & Olive laminated limestone & 1.5 & 10.7 & -27.8 & 270 & 67 & 402 \\
\hline $36-2,1-5$ & Olive laminated limestone & 6.8 & - & -28.0 & 655 & 35 & 407 \\
\hline $36-2,84-88$ & Olive laminated limestone & 4.7 & - & -27.6 & 655 & 56 & 410 \\
\hline $37-2,22-24$ & Olive laminated limestone & 4.7 & 10.0 & -28.2 & 607 & 83 & 400 \\
\hline $37-2,25-29$ & Olive laminated limestone & 6.0 & 9.5 & -28.3 & 650 & 42 & 397 \\
\hline $38-1,142-150$ & Olive laminated limestone & 3.6 & - & -27.5 & 632 & 45 & 411 \\
\hline $465 \mathrm{~A}^{\mathrm{e}}$ & Olive laminated limestone & 6.8 & 9.1 & -28.5 & 631 & 66 & 391 \\
\hline $465 \mathrm{~A}^{\mathrm{e}}$ & Olive laminated limestone & 3.5 & 3.1 & -25.8 & 388 & 71 & 402 \\
\hline $465 \mathrm{~A}^{\mathrm{e}}$ & Olive laminated limestone & 4.9 & 3.7 & -27.9 & 450 & 59 & 400 \\
\hline $465 \mathrm{~A}^{\mathrm{e}}$ & Olive laminated limestone & 7.8 & 9.3 & -28.0 & 676 & 60 & 396 \\
\hline $466-28, C C$ & Olive limestone & 2.7 & 0.08 & -27.8 & 301 & 44 & 403 \\
\hline $29-1,46-51$ & Olive limestone & 7.5 & - & -28.8 & 652 & 44 & 409 \\
\hline $29-1,62-66$ & Olive limestone & 8.1 & 8.4 & -28.8 & 648 & 42 & 400 \\
\hline $29-1,139-144$ & Olive limestone & 8.6 & - & -28.4 & 687 & 39 & 418 \\
\hline
\end{tabular}

${ }^{a} \mathrm{Mg} \mathrm{S}_{2}$ (hydrocarbons) per $\mathrm{g}$ organic carbon, Rock-Eval pyrolysis.

b $\mathrm{Mg} \mathrm{S}_{3}$ (carbon dioxide) per $\mathrm{g}$ organic carbon, Rock-Eval pyrolysis.

${ }^{c}$ Temperature $\left({ }^{\circ} \mathrm{C}\right)$ at which the yield of pyrolysis products is at a maximum, Rock-Eval. pyrolysis.

d Labels came off in shipping; samples are either from Core 70 or 71 .

e Labels came off in shipping; samples are either from Core 32 or 38 .

f Indicates no determination.

been close to the equator 98 to $103 \mathrm{~m}$.y. ago, during deposition of organic-carbon-rich strata at that site.

All three sites undoubtedly were close to volcanic islands during the mid-Cretaceous. Volcanic ash and organic matter are closely associated at both Sites 463 and 465, suggesting that sources of these two components somehow may be related. In Hole $465 \mathrm{~A}$, the first occurrences of both volcanic ash and abundant organic matter are in Core 40, Section 2, 0-4 cm, only $60 \mathrm{~cm}$ above volcanic basement. The organic-carbonrich laminated limestone contains Albian benthic foraminifers from upper bathyal depths, and common redeposited materials. Thin beds of clastic limestone containing clasts of trachyte are intercalated at the base of the laminated limestone section. All these observations suggest that the laminated limestone was deposited in relatively shallow water, although the common radiolarians, now mostly replaced by $\mathrm{CaCO}_{3}$, imply that there was also a significant pelagic contribution.

In Hole 463, the thin, ash- and organic-carbon-rich unit lies above interbedded pelagic and clastic limestones containing shallow-water carbonate debrisoolites and fragments of stromatolites, coral, and large mollusks - derived from adjacent carbonate banks (see lithologic summary in Site 463 report, this volume). This sequence suggests rapid subsidence of the site from the late Barremian to the early Aptian.
Judging from these observations, we expected the organic-carbon-rich strata on both Hess Rise and the Mid-Pacific Mountains to contain significant terrestrial organic matter derived from nearby tropical islands during the mid-Cretaceous. However, the pyrolysis assays (Table 1; Fig. 9) show that most of the organic matter in samples from Holes $465 \mathrm{~A}$ and 466 has hydrogen indexes greater than 400 , which indicates that the organic matter is lipid-rich (sapropelic) and derived from marine organisms.

Samples from Hole 463 contain lower concentrations of organic carbon than those from Holes 465A and 466, which makes interpretation of pyrolysis analyses more tenuous. However, the Hole 463 samples tend to have low hydrogen indexes, high oxygen indexes, and low ratios of hydrocarbon compounds to organic carbon (Table 1; Fig. 9). These characteristics suggest that a significant proportion of the organic matter in samples from Hole 463 might be derived from land plants, although this was not confirmed by detailed analyses of extractable lipids, which show that in samples containing a significant amount of preserved organic matter ( $>2 \%$ organic carbon) it is dominantly of marine origin (Table 2, Fig. 10).

The carbon-isotope data (Fig. 11) indicate that samples of the lipid-rich (high hydrogen index) laminated limestone from Hole 465A tend to be isotopically lighter 


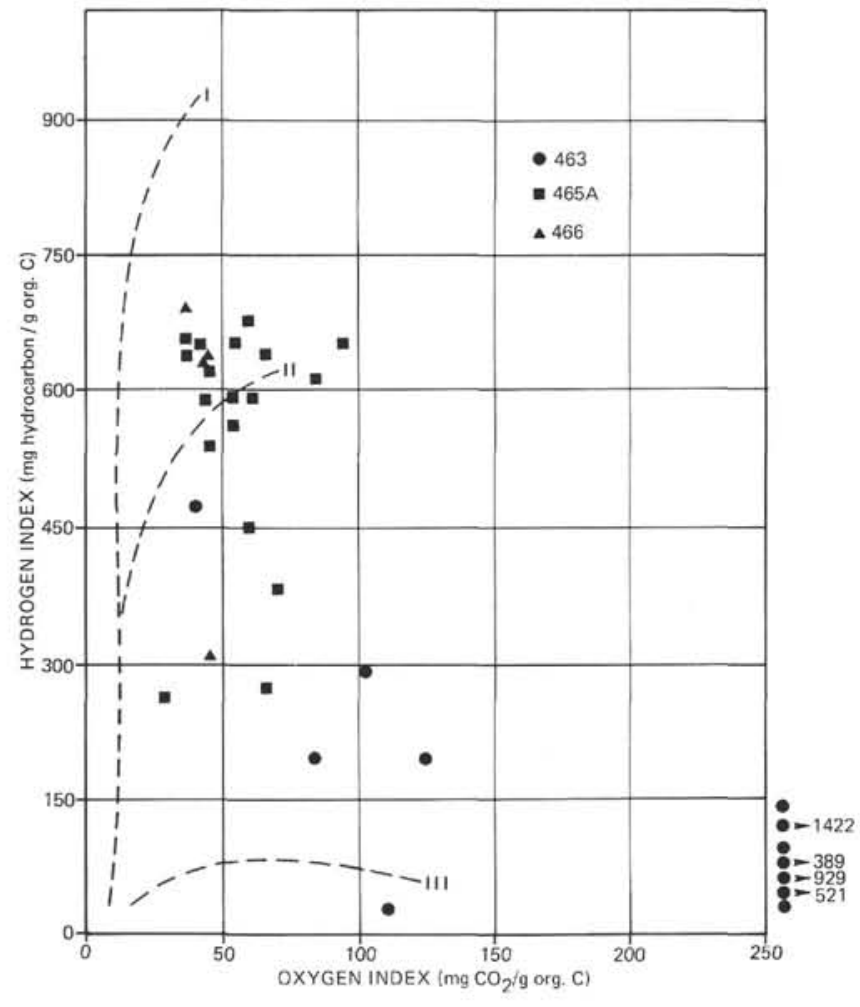

Figure 9. Scatter diagram of hydrogen and oxygen indexes for Holes $463,465 \mathrm{~A}$, and 466 . Roman numerals and dashed lines refer to thermochemical transformation pathways of three different types of sedimentary organic matter. (See text for discussion.)

Table 2. Summary of extractable organic matter of limestones from DSDP Sites 463 and 465.

\begin{tabular}{lcccc}
\hline $\begin{array}{c}\text { Sample } \\
\text { (interval in cm) }\end{array}$ & $\begin{array}{c}\text { Bitumen }^{\mathrm{a}} \\
(\mathrm{ppm})\end{array}$ & $\begin{array}{c}\text { Total } \\
\text { Hydrocarbons } \\
(\mathrm{ppm})\end{array}$ & $\begin{array}{c}\text { HC/org. C } \\
(\%)\end{array}$ & $\begin{array}{c}\text { HC/bitumen } \\
(\%)\end{array}$ \\
\hline $463-59-3,73-83$ & 16 & 14 & 4.6 & 88 \\
$463-70-6,29-35^{\mathrm{C}}$ & 378 & 175 & 0.70 & 46 \\
$463-70-6,39-42^{\mathrm{C}}$ & 11 & 8 & 8.2 & 73 \\
$463-72-4,132-140$ & 1530 & 44 & 0.12 & 2.9 \\
$465 \mathrm{~A}-38-1,142-150$ & 152 & &
\end{tabular}

${ }^{a}$ Extracted 20 hours with chloroform in soxhlet apparatus; sulfur removed by refluxing with copper.

b Sum of heptane and benzene eluates from silica-gel column chromatography.

c Samples combined in equal weight proportions to obtain sufficient material for extraction.

$\left(\delta^{13} \mathrm{C}-29\right.$ to $\left.-27 \%\right)$, whereas samples of limestones with less-hydrogen-rich organic matter, especially those from Hole 463 , tend to be isotopically heavier $\left(\delta^{13} \mathrm{C}\right.$ -27 to $-24 \%$ ). This is the opposite of what we would expect if the less-hydrogen-rich organic matter contained a significant contribution from terrestrial vegetation, which contains isotopically light carbon $\left(\delta^{13} \mathrm{C}-21\right.$ to $-32 \%$; Craig, 1954 ) relative to marine organic matter $\left(\delta^{13} \mathrm{C}-13\right.$ to $-23 \%$; Degens, 1969$)$. This is also the opposite of what we would expect from differential preservation during diagenesis, because ${ }^{12} \mathrm{C}$-rich (lighter) organic compounds are more labile, and ${ }^{13} \mathrm{C}$-rich (heavier) organic compounds more resistant; we would therefore expect organic matter to become isotopically heavier during diagenesis.

Most tropical terrestrial organic carbon is at the lighter end of the range -21 to $-32 \%$ ); for example, Williams (1968) gave a range of -28.5 to $-29.4 \%$ for $\delta^{13} \mathrm{C}$ of dissolved and particulate organic matter in the Amazon River. The total range of $\delta^{13} \mathrm{C}$ values for modern marine organic matter taken from the literature is about -13 to $-30 \%$ (Fig. 12).

The actual value is in part dependent on temperature. For example, according to experimental studies by Deuser et al. (1968), typical values of $\delta^{13} \mathrm{C}$ in cold-water plankton should be about $-28 \%$; typical values in warm-water plankton should be about $-13 \%$. Most $\delta^{13} \mathrm{C}$ values for marine plankton are in the approximate range -18 to $-20 \%$ (Craig, 1953; Sackett et al., 1965; Degens et al., 1968; Williams and Gordon, 1970). Organic matter in Holocene marine sediments tends to have $\delta^{13} \mathrm{C}$ values of about $-23 \%$ in warm regions (e.g., Sackett, 1964; Eckelmann et al., 1962) and slightly higher values (ca. - 15\%) in cold regions (e.g., Sackett et al., 1965).

If the organic matter in mid-Cretaceous rocks at Sites 463,465 , and 466 was derived from tropical marine organisms, and particularly if surface-water temperatures were higher than they are now, we would expect $\delta^{13} \mathrm{C}$ values to be toward the heavier end of the range of values for modern marine organic matter shown in Figure 12 (perhaps $-20 \%$ or heavier).

The values of $\delta^{13} \mathrm{C}$ for organic matter at Sites 463, 465 , and 466 (Table 1; Fig. 11) are within the ranges for Cretaceous petroleum and organic-carbon-rich strata from other localities (Fig. 12). The light values of $\delta^{13} \mathrm{C}$ in some organic-carbon-rich strata has led some investigators to conclude that a light carbon-isotope composition supports a terrigenous origin for at least some of the organic matter (e.g., Calder et al., 1974; Simoneit, 1978a, b). However, the chemical analyses suggest that most of the organic matter in the organic-carbonrich strata on both Hess Rise and the Mid-Pacific Mountains is marine, and that the isotopically lightest organic matter is the most marine (hydrogen-rich).

Other than the somewhat equivocal isotopic evidence, there is no indication of significant contribution of terrestrial organic matter to the organic-carbon-rich mid-Cretaceous limestones on Hess Rise and the MidPacific Mountains, even though the equatorial locations and shallow depths of the sites during the mid-Cretaceous suggest that contributions of terrestrial organic matter were possible.

\section{ORIGIN OF ORGANIC-CARBON-RICH STRATA}

The accumulation of organic-carbon-rich sediments in the ocean requires a high rate of supply of organic detritus, coupled with either anoxic bottom waters or rapid sedimentation. If the sediments are laminated, we can assume that there were no burrowing organisms, and that the bottom waters probably were anoxic. Anoxic conditions reduce inorganic oxidation of organic matter and destruction of organic matter by detritus 
A $463-59-3,73-83 \mathrm{~cm}$

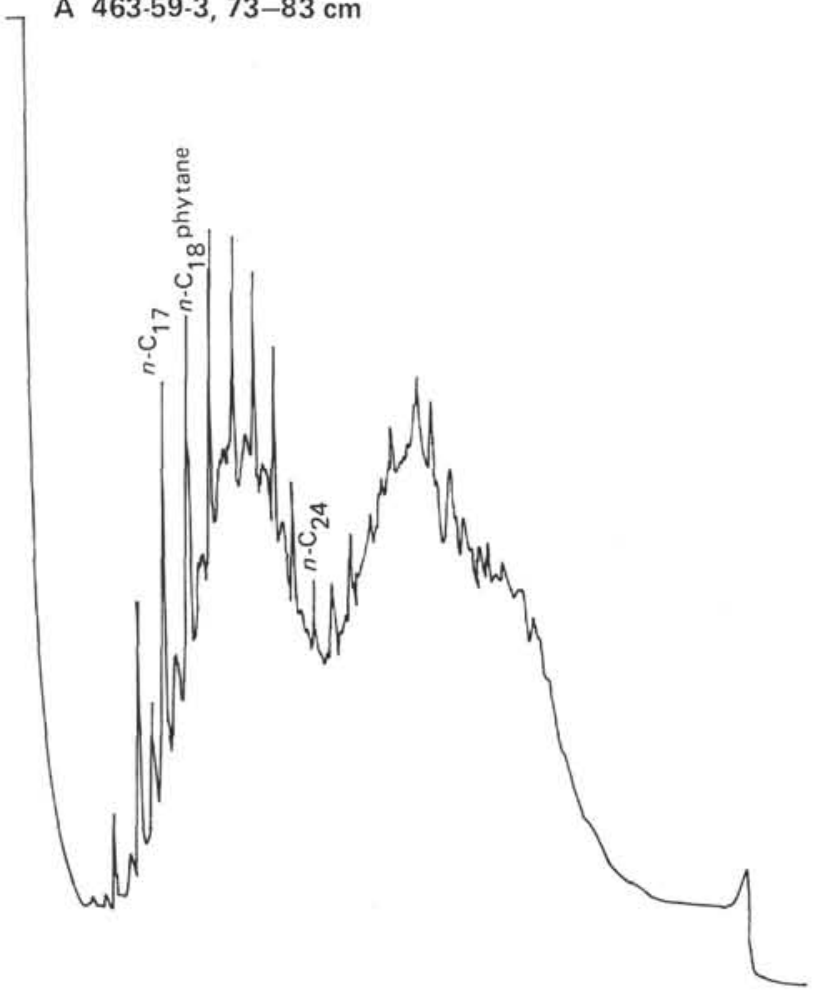

B $463 \cdot 70-6,29-35 \mathrm{~cm}$ and $39-42 \mathrm{~cm}$

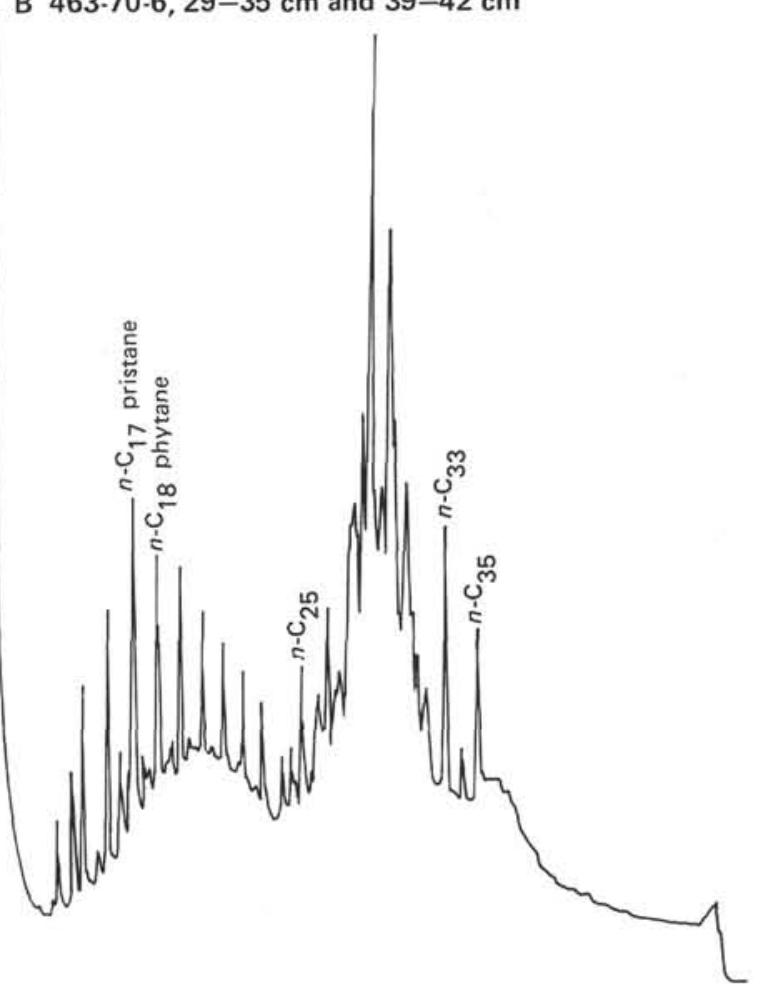

C $463-72-4,132-140 \mathrm{~cm}$

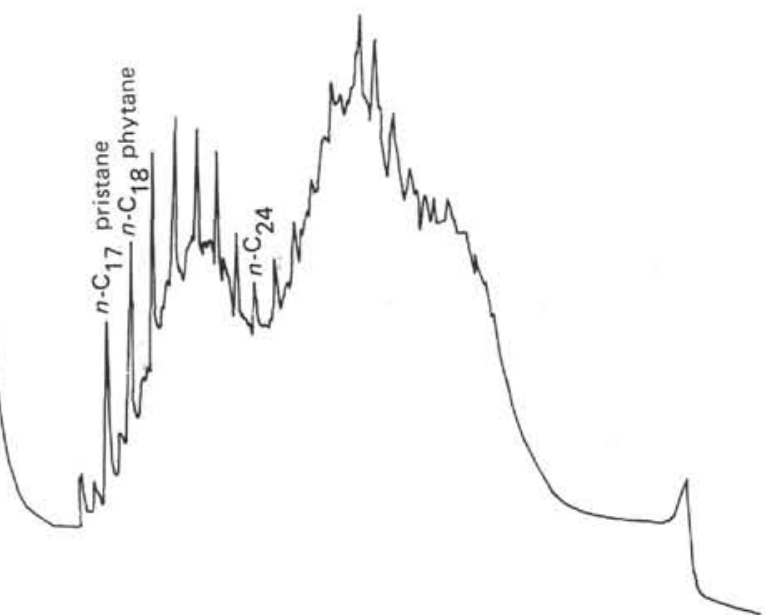

D $465 \mathrm{~A}-38-1,142-150 \mathrm{~cm}$

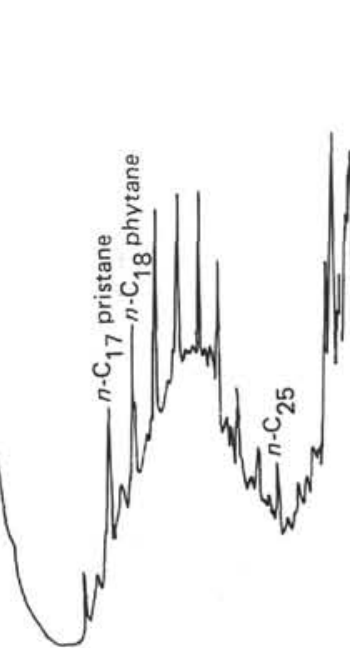

照

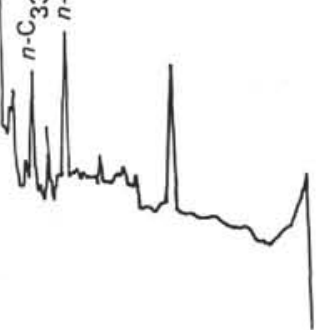

Figure 10. Gas chromatograms of the saturated-hydrocarbon fractions (heptane eluates). 


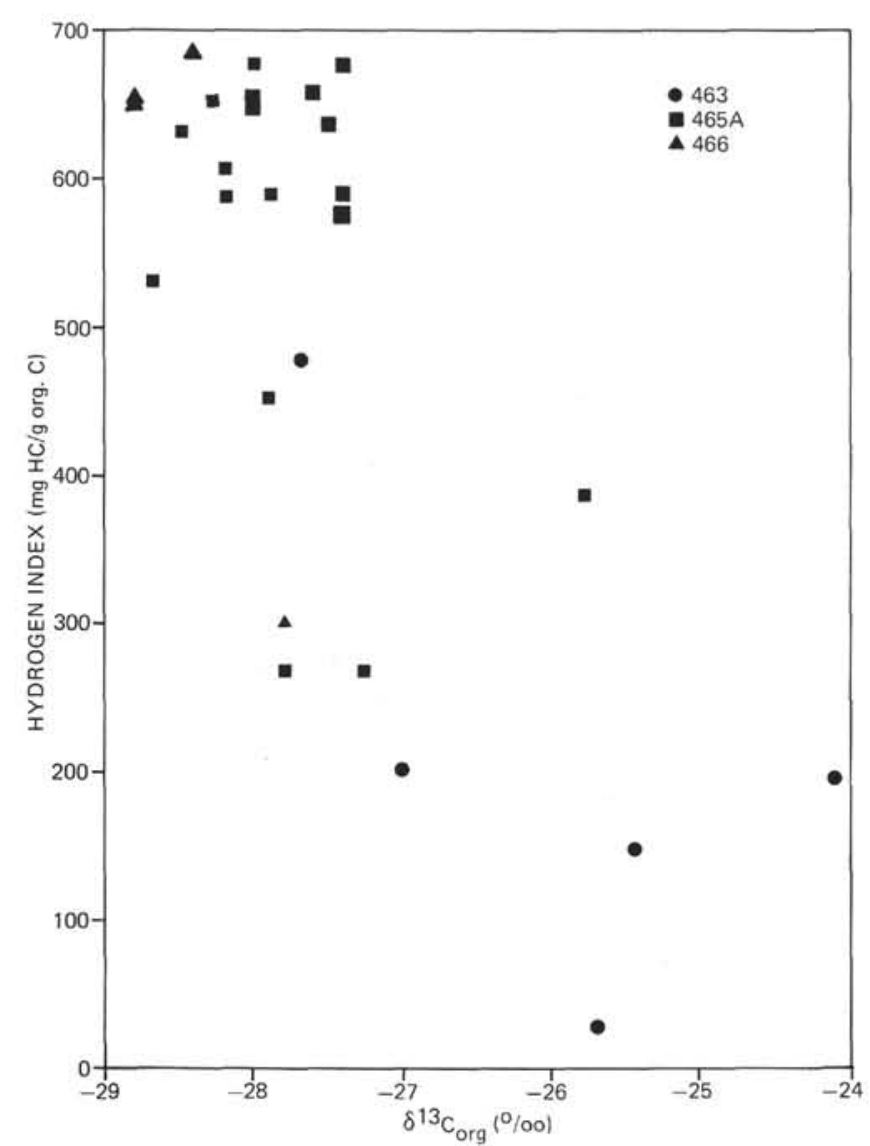

Figure 11. Scatter plot of hydrogen index and $\delta^{13} \mathrm{C}$ (relative to $\mathrm{PDB}$ standard) for samples of organic-carbon-rich limestone from Holes 463, 465A, and 466 .

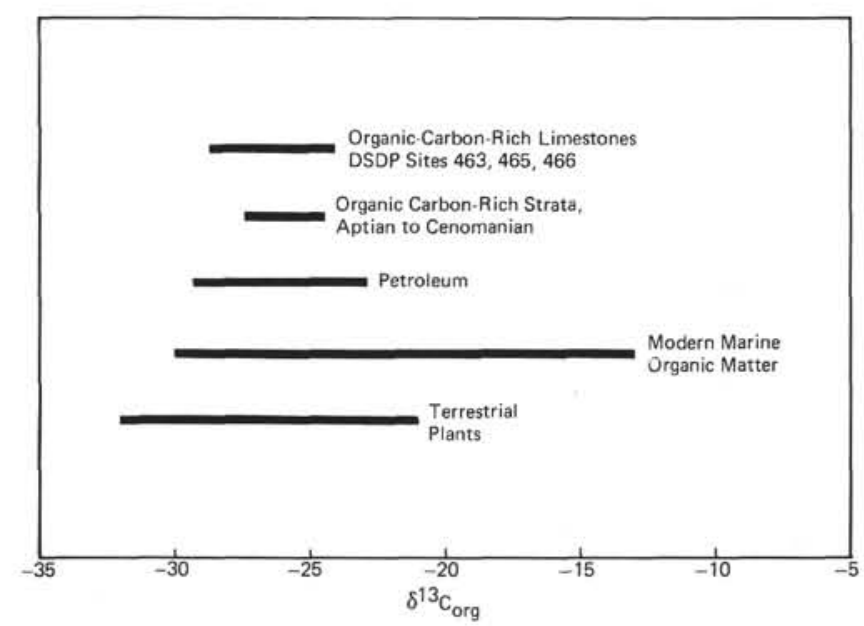

Figure 12. Ranges of $\delta^{13} \mathrm{C}$ (relative to PDB standard) for organic carbon in limestones from Sites 463,465 , and 466 ; organic-carbonrich mid-Cretaceous Aptian-Cenomanian strata from other localities (Craig, 1953; Rogers et al., 1972; Calder et al., 1974; Simoneit, 1978a, b); petroleum (Craig, 1954); modern marine organic matter (Craig, 1953; Sackett and Thompson, 1963; Sackett et al., 1965; Degens et al., 1968; Degens, 1969; Deuser et al., 1968; Williams and Gordon, 1970); and terrestrial plants (Craig, 1954). feeders and aerobic bacteria. Laminated sediments containing high concentrations of organic carbon (5-10\% or more) are therefore generally taken to indicate deposition in an anoxic, or at least oxygen-deficient, environment. The high concentrations of organic carbon (Figs. 3, 4, and 7) and the laminations in mid-Cretaceous limestones at Sites 463,465 , and 466 suggest that these limestones were deposited in oxygen-deficient environments.

Two basic models have been proposed to represent depositional environments of marine sediments rich in organic matter (Schlanger and Jenkyns, 1976; Ryan and Cita, 1977; Fischer and Arthur, 1977; Thiede and van Andel, 1977; Arthur and Schlanger, 1979). The first model is a chemically stratified, barred basin with anoxic deep waters. The most commonly used example of this type of environment is the present Black Sea. The second type of environment occurs where an oceanic mid-water oxygen minimum impinges on a continental margin or oceanic plateau. Examples of this type of environment occur today along the continental margins of the subtropical eastern Pacific Ocean and the northern Indian Ocean.

Both of these models require very low to nil oxygen concentrations in part of the water column as a result of reduced advection of oxygenated waters and (or) increased supply of organic matter, and both imply that reducing conditions in the sediments (and therefore preservation of accumulating organic matter) are the result of low-oxygen conditions in the overlying waters.

A third model is also possible, in which reducing conditions in the sediments are the result of a high biological oxygen demand, which in turn is due to a high rate of supply of organic detritus to the sediments (e.g., Gardner et al., 1978). Examples of this type of environment include the southern Bering Sea, continental shelves, and the ancient Black Sea. In these environments the bottom waters are oxygenated $(>2.0 \mathrm{ml} / 1$ $\mathrm{O}_{2}$ ), and the $\mathrm{O}_{2}=0$ isopleth is at or near the sediment/water interface. The sediments are green (usually various shades of greenish-gray or olive), and concentrations of organic carbon are $>0.5 \%$, commonly several percent. The amount of organic carbon preserved is a function of the rate of supply of organic detritus and the rate of sediment accumulation; restricted bottom-water circulation is not necessary.

The conditions represented by the first and third models (closed basin and high rate of supply of organic matter) could result in accumulation of organic-carbonrich anoxic sediments over wide areas of the sea floor. The conditions represented by the second model (midwater oxygen minimum) would normally result in a "bathtub ring" of reduced sediment wherever the oxygen minimum impinges on the margins of the basin or on mid-basin plateaus. However, expansion and intensification of the oxygen-minimum zone due to an increase in organic productivity and (or) a reduction of bottom-water circulation could result in the accumulation of organic-carbon-rich anoxic sediments over a much greater area (Fischer and Arthur, 1977). 
The expanded-oxygen-minimum model is generally used to explain the common organic-carbon-rich midCretaceous sediments in the Atlantic Ocean, parts of the Indian Ocean, and elevated plateaus in the Pacific Ocean (e.g., Schlanger and Jenkyns, 1976; Fischer and Arthur, 1977; Thiede and van Andel, 1977; Arthur and Schlanger, 1979). These sediments are so widespread in the Atlantic Ocean that the closed-basin model has been suggested as a possible analog for the Early Cretaceous to mid-Cretaceous Atlantic Ocean (Ryan and Cita, 1977; Thiede and van Andel, 1977; Arthur and Schlanger, 1979).

Organic-carbon-rich strata along the continental margin of northwest Africa range in age from Jurassic to Holocene, and application of the anoxic-basin model is difficult for so long a time. Dean et al. (1978) and Gardner et al. (1978) suggested that variations in rate of supply of organic detritus, much of which may be terrestrial (Habib, 1979; Simoneit, 1978a; Tissot et al., 1979), caused the cyclic interbeds of more-reduced and less-reduced strata ranging in age from Late Jurassic to Eocene along the continental margin of northwest Africa.

The most striking feature of the organic-carbon-rich mid-Cretaceous strata in the Pacific Ocean is that they occur only on elevated plateaus and rises such as Horizon Guyot (Site 171; Winter, Ewing, et al., 1973), Manihiki Plateau (Site 317; Schlanger, Jackson, et al., 1976), Shatsky Rise (Site 305; Larson, Moberly, et al., 1975), northern Hess Rise (Site 310; Larson, Moberly, et al., 1975), southern Hess Rise (Sites 465 and 466; this volume), and Mid-Pacific Mountains (Site 463; this volume), and not in adjacent basins-and most occur within fairly narrow time intervals. Southern Hess Rise is the only locality in the Pacific where high concentrations of organic carbon are contained in relatively thick (tens of meters) sections spanning several millions of years, to perhaps as much as 10 m.y.

Ocean temperatures probably were also at a maximum during the mid-Cretaceous (Douglas and Savin, 1975; Fischer and Arthur, 1977). Increased surfacewater temperatures would have had two main effects: first, thermohaline deep-water circulation, driven today mainly by the sinking of cold, oxygen-rich waters in high latitudes, would have been more sluggish than now; and, second, the warmer deep-water mass initially would have contained less dissolved oxygen. The observations that the carbon-rich horizons at Pacific localities all occur within the mid-Cretaceous, but are not all strictly synchronous (ranging in age from Barremian to Turonian) and that all but the southern Hess Rise localities occur within narrow time limits suggest that sediment accumulation was influenced by local conditions of circulation within a general regime of reduced mid-water oxygen concentration.

The local depositional environments favorable for the preservation of organic matter may have been created by the volcanic event that produced the volcanic ash associated with the higher concentrations of organic carbon. All of these observations suggest that the expanded-oxygen-minimum model, modified by local circulation patterns and sedimentation conditions, best explains the formation of organic-carbon-rich mid-Cretaceous strata in the Pacific Ocean.

The expanded oxygen minimum likely was the result of high equatorial surface-water productivity, augmented by more-sluggish circulation of bottom water containing lower concentrations of dissolved oxygen (Schlanger and Jenkyns, 1976; Ryan and Cita, 1977; Fischer and Arthur, 1977; Thiede and van Andel, 1977).

\section{REFERENCES}

Arthur, M. A., 1979. North Atlantic Cretaceous black shales: the record at Site 398 and a brief comparison with other occurrences. In Sibuet, J.-C., Ryan, W. B. F., et al., Init. Repts. DSDP, 47, Pt. 2: Washington (U.S. Govt. Printing Office), 719-751.

Arthur, M. A., and Schlanger, S. O. 1979. Cretaceous "oceanic anoxic events" as causal factors in development of reef-reservoired giant oilfields. Bull. Am. Assoc. Petrol. Geol., 63:870-885.

Calder, J. A., Horvath, G. J., Shultz, D. J., et al., 1974. Geochemistry of the stable carbon isotopes in some Indian Ocean sediments. In Davies, T. A., Luyendyk, B. P., et al., Init. Repts. DSDP, 26: Washington (U.S. Govt. Printing Office), 613-617.

Claypool, G. E., and Baysinger, J. P., in press. Analysis of organic matter in sediment cores from the Moroccan Basin Deep Sea Drilling Project Sites 415 and 416. In Lancelot, Y., Winterer, E. L., et al., Init. Repts. DSDP, 50: Washington (U.S. Govt. Printing Office).

Craig, H., 1953. The geochemistry of stable carbon isotopes. Geochim. Cosmochim. Acta, 3:53-92.

1954. Geochemical implications of the isotopic composition of carbon in ancient rocks. Geochim. Cosmochim. Acta, 6:186-196.

Dean, W. E., Gardner, J. V., Jansa, L. F., et al., 1978. Cyclic sedimentation along the continental margin of northwest Africa. In Lancelot, Y., Siebold, E., et al., Init. Repts. DSDP, 41: Washington (U.S. Govt. Printing Office), 965-986.

Degens, E. T., 1969. Biogeochemistry of stable carbon isotopes, In Eglinton, G., and Murphy, M. T. J. (Eds.), Organic Geochemistry, Methods and Results: Berlin (Springer-Verlag), pp. 304-329.

Degens, E. T., Behrendt, M., Gotthardt, B., et al., 1968. Metabolic fractionation of carbon isotopes in marine plankton. II. Data on samples off the coasts of Peru and Ecuador. Deep Sea Res., 15:11-20.

Deuser, W. G., Degens, E. T., and Guillard, R. R. L., 1968. Carbon isotope relationships between plankton and sea water. Geochim. Cosmochim. Acta, 32:657-660.

Douglas, R. G., and Savin, S. M., 1975. Oxygen and carbon isotope analyses of Tertiary and Cretaceous microfossils from Shatsky Rise and other sites in the North Pacific Ocean. In Larson, R. L., Moberly, R. et al., Init. Repts. DSDP, 32: Washington (U.S. Govt. Printing Office), 509-521.

Eckelmann, W. R., Broecker, W. S., Whitlock, D. W., et al., 1962. Implication of carbon isotopic composition of total organic carbon of some recent sediments and ancient oils. Bull. Am. Assoc. Petrol. Geol., 46:699-704.

Espitalié, J., LaPorte, J. L., Madec, M., et al., 1977. Mèthode rapide de caractèrisation des roches mères de leur potential pétrolier et de leur degré d'evolution. Rev. Inst. Français Petrolé, 32:23-42.

Fischer, A. G., and Arthur, M. A., 1977. Secular variations in the pelagic realm. In Cook, H. E., and Enos, P. (Eds.), Deep Water Carbonate Environments: Soc. Econ. Paleont. Mineral. Spec. Pub., 25:19-50.

Gardner, J. V., Dean, W. E., and Jansa, L. F., 1978. Sediments recovered from the northwest African continental margin, Leg 41, DSDP. In Lancelot, Y., Seibold, E., et al., Init. Repts. DSDP, 41: Washington (U.S. Govt. Printing Office), 1121-1134.

Habib, D., 1979. Sedimentary origin of North Atlantic Cretaceous palynofacies. In Talwani, M., Hay, W., and Ryan, W. B. F. (Eds.), Deep Drilling Results in the Atlantic Ocean: Continental Margins and Paleoenvironments: Am. Geophys. Union, Maurice Ewing Ser., 3:420-437. 
Kaplan, I. R., Smith, J. W., and Ruth, E., 1970. Carbon and sulfur concentration and isotopic composition in Apollo 11 lunar samples (Proc. Apollo 11 Lunar Scientific Conf.) Geochim. Cosmochim. Acta, Suppl. 2:1317-1329.

Lancelot, Y., 1978. Relations entre évolution sédimentaire et tectonique de la Plaque Pacifique depuis le Crétacé Inférieur. Soc. Géol. France Mém., 134.

Lancelot, Y., and Larson, R. L., 1975. Sedimentary and tectonic evolution of the northwestern Pacific. In Larson, R. L., Moberly, R., et al., Init. Repts. DSDP, 32: Washington (U.S. Govt. Printing Office), 925-939.

Larson, R. L., Moberly, R., et al., 1975. Init. Repts. DSDP, 32: Washington (U.S. Govt. Printing Office).

Rogers, M. A., van Hinte, J. E., and Sugden, J. G., 1972. Organic carbon $\delta^{13} \mathrm{C}$ values from Cretaceous, Tertiary, and Quaternary marine sequences in the North Atlantic. In Laughton, A. S., Berggren, W. A., et al., Init. Repts. DSDP, 12: Washington (U.S. Govt. Printing Office), 1115-1126.

Ryan, W. B. F., and Cita, M. B., 1977. Ignorance concerning episodes of ocean-wide stagnation. Mar. Geol., 23:197-215.

Sackett, W. M., 1964. The depositional history and isotopic organic carbon composition of marine sediments. Mar. Geol., 2:173-185.

Sackett, W. M., Eckelmann, W. R., Bender, M. L., et al., 1965. Temperature dependence of carbon isotope composition in marine plankton and sediments. Science, 148:235-237.

Sackett, W. M., and Thompson, R. R., 1963. Isotopic organic composition of recent continental derived clastic sediments of eastern Gulf coast, Gulf of Mexico. Bull. Am. Assoc. Petrol. Geol., 47:525-531.

Schlanger, S. O., Jackson, E. D., et al., 1976. Init. Repts. DSDP, 33: Washington (U.S. Govt. Printing Office).

Schlanger, S. O., and Jenkyns, H. C., 1976. Cretaceous oceanic anoxic events-causes and consequences. Geol. Mijnbouw, $55: 179-184$.
Simoneit, B. R. T., 1978a. Leg 41 sediment lipids-search for eolian organic matter in recent samples and examination of a black shale. In Lancelot, Y., Siebold, E., et al., Init. Repts. DSDP, 41: Washington (U.S. Govt. Printing Office), 855-858.

, 1978b. Lipid analyses of sediments from Site 464 in the Angola Basin, DSDP Leg 40. In Bolli, H. M., Ryan, W. B. F., et al., Init. Repts. DSDP, Suppl. to Vols. 38, 39, 40, and 41: Washington (U.S. Govt. Printing Office), 659-662.

Thiede, J., and van Andel, Tj. H., 1977. The paleoenvironment of anaerobic sediments in the late Mesozoic South Atlantic Ocean. Earth Planet. Sci. Lett., 33:301-309.

Tissot, B., Deroo G., and Herbin, J. P., 1979. Organic matter in Cretaceous sediments of the North Atlantic: contributions to sedimentology and paleogeography. In Talwani, M., Hay, W., and Ryan, W. B. F. (Eds.), Deep Drilling in the Atlantic Ocean: Continental Margins and Paleoenvironment: Am. Geophys. Union, Maurice Ewing Ser., 3:362-374.

Tissot, B., Durand, B., Espitalié, J., et al., 1974. Influence of nature and diagenesis of organic matter in formation of petroleum. Bull. Am. Assoc. Petrol. Geol., 58:499-506.

Tissot, B., and Welte, D. H., 1978. Petroleum Formation and Occurrences: New York (Springer-Verlag).

Tucholke, B. F., and Vogt, P. R., 1979. Western North Atlantic: sedimentary evolution and aspects of tectonic history. In Tucholke, B. E., et al., Init. Repts. DSDP, 43: Washington (U.S. Govt. Printing Office), $791-825$.

van Hinte, J. E., 1976. A Cretaceous time scale. Bull. Am. Assoc. Petrol. Geol., 60:498-516.

Williams, P. M., 1968. Organic and inorganic constituents of the Amazon River. Nature, 218:937-938.

Williams, P. M., and Gordon, L. I., 1970. Carbon-13:carbon-12 ratios in dissolved and particulate organic matter in the sea. Deep Sea Res., 17:19-27.

Winterer, E. L., Ewing, J. I., et al., 1973. Init. Repts. DSDP, 17: Washington (U.S. Govt. Printing Office). 